predictability as to the degree of success our efforts will achieve and even the precise course we shall decide to follow as problems are presented to us. This is not, however, a cry of disappointment and despair that the destinies of meteorology and the AMS are so closely coupled to forces beyond our control. Rather, it is a recognition that it is precisely this close linkage that demonstrates the importance of our science and our profession to major public needs and objec- tives. We recognize more than ever before the vital role that the atmosphere plays in our lives, while at the same time our abilities to observe the atmosphere and to understand its processes have never been as great. For these reasons, I believe we can be confident that even though our course may be turbulent, the atmospheric sciences will continue to be an exciting arena in which to work and to contribute vitally to human welfare.

\title{
Report of the Ballot Tellers-December 23, 1981
}

Dear Dr. Simpson:

Attached are the results of the 1982 Ballot, tallied from a total of 3538 ballots cast by the voting members of the Society for the offices of President-Elect and Councilor.

For President-Elect

Stanley A. Changnon, Jr. 1701 Earl G. Droessler
For Councilor

Neil L. Frank

Charlotte J. Hopper

Lynn L. LeBlanc

Sharon K. LeDuc

Howard Reiquam

Robert T. Ryan

Bernard A. Silverman

Paul F. Twitchell

Thomas H. Vonder Haar 1856
2237 President-Elect:

1049 Earl G. Droessler

1262 Councilors:

1316 Neil L. Frank

886 Robert T. Ryan

1684 Paul F. Twitchell

1106 Thomas H. Vonder Haar

Ballot Tellers for 1982: Paul E. Sherr, Chairman; Donald A. Chisholm; Owen R. Cote; VAlentine J. Descamps; John D. SPENGLER

\section{Report of the Secretary-Treasurer for 1981}

\section{Meetings of the Council and Executive Committee}

The Council of the American Meteorological Society met in San Diego, Calif., on January 18 and 19, and in Boston on October 1 and 2, 1981.

The Executive Committee met in San Diego, Calif., on January 17 and 19, and in Boston on June 1 and 2 and September 30, 1981.

\section{Publications}

The publications activities were as follows:

$\begin{array}{lc} & \text { Pages } \\ \text { BUlletiN OF THE AMERICAN METEOROLOGICAL } & 1792 \\ \text { SOCIETY } & 2824 \\ \text { JOURNAL OF THE AtMOSPHERIC SCIENCES } & 1564 \\ \text { JOURNAL OF APPLIED METEOROLOGY } & 1694 \\ \text { JOURNAL OF PHYSICAL OCEANOGRAPHY } & 2564 \\ \text { MONTHLY WEATHER REVIEW } & \\ \text { METEOROLOGICAL AND GEOASTROPHYSICAL } & 2539 \\ \text { A BSTRACTS } & \end{array}$

MGA ANNUAL INDEXES

Vol. 31, Jan.-Dec. 1980 